\author{
I. Ishchenko, Dr. Sc. (Polit.), Cand. Sc. (Hist.), \\ Assoc. Prof., \\ orcid.org/0000-0001-5799-7364, \\ O. Vysotskyi, Dr. Sc. (Polit.), Cand. Sc. (Hist.), Prof., \\ orcid.org/0000-0003-0712-8499, \\ V. Perminov, Cand. Sc. (Polit.), \\ orcid.org/0000-0003-0897-1269
}

\title{
TECHNOLOGY FOR DETERMINING THE EFFECTIVENESS OF INTERNATIONAL COOPERATION IN THE MINING INDUSTRY
}

Purpose. Defining the priority areas of international cooperation that can radically change the situation in the mining industry of Ukraine for the better, the criteria for their evaluation, as well as technologies (tools) of the effective international cooperation in this area.

Methodology. Structural and component analysis of the problematic issues of the development of the mining industry of Ukraine was used to achieve the purpose of this study. General scientific methods including the comparative and analogy methods, and the descriptive analysis played were also applied.

Findings. It has been found that in terms of the gross value of minerals in the subsoil prepared for exploitation, Ukraine ranks first in Europe. For some types of minerals, production exceeds consumption. At the same time, back in the 70s of the last century, Ukraine provided itself with its own resources and produced, among other things, almost 70 billion cubic meters of natural gas. However, today the characteristic features of the Ukrainian mining industry are inefficiency, imbalance, and lack of innovation. It has been proved that the impetus for economic growth in this situation will be the presence of significant investments in the development of the mining industry, primarily in nanotechnology. The necessity of international cooperation in order to improve the situation in the industry has substantiated. A scheme of technology for determining the effectiveness of international cooperation in the mining industry has been developed.

Originality. A comprehensive study of the mining industry of Ukraine was carried out in the context of the opportunities provided by international cooperation in this area. A model for assessing the effectiveness of this cooperation has been proposed.

Practical value. The theses substantiated in the study and the proposed models for determining the effectiveness of international cooperation are suitable for the use in the planning of regional development and for the preparation of relevant state programs.

Keywords: mining, economic growth, investment, demonopolization, synchro-mining, innovation

Introduction. The state of things in the mining industry of Ukraine is a mirror image of the situation in the state as a whole. A country that has the potential to be one of the largest suppliers of gas and coal to Europe should earn a lot of money on the export of raw materials, but is not able to provide itself, even in critically needed volumes. Another specific feature is the ability to receive excess profits from enterprises that are deeply unprofitable, and have arrears of wages for several months. Whether Ukraine will retain its sovereignty in the near future actually depends on the remediation of this situation. It can be assumed that it is useless to hope for self-regulation and self-improvement in this case. We have been expecting major changes for decades. It is possible to radically change the mining industry through international cooperation, but it is important to choose the right vector. A mistake in this choice can "preserve" the existing order and lead to further stagnation and regression. Thus, there is a question of developing technologies to determine the effectiveness of international cooperation in the mining industry.

Literature review. Various aspects of the functioning of the mining industry, such as its general condition and development prospects, opportunities and risks of innovation in the industry, its role in ensuring the economic security of the country, were comprehensively covered by Ukrainian scientists (M. V. Boichenko, O.V. Bondar-Pidhurska, T.D. Hanziuk, M. O. Kovalenko, V.A. Kovalchuk, V.Y. Korotkyi, S. Y. Shatska). General issues defining the industry as a key element of strategic development (L.V. Deineko, V.V.Zimovets, N. M. Sheludko), as well as applied issues, such as the implementation of synchromining concept (G. G. Pivnyak, P. I. Pilov, M.S. Pashkevich, D.A. Shashenko ), labor safety of coal mining enterprise (O. A. Russiyan, V. V. Karnaukh).

(C) Ishchenko I., Vysotskyi O., Perminov V., 2020
Unsolved aspects of the problem. Together with the unconditional recognition of the fact that the existing body of literature on the state of things and prospects for the development of the mining industry has been covered comprehensively and in detail, it is impossible not to see that the overall picture looks somewhat pessimistic. Ukraine is not able to realize its great potential because of falling out of the international division of labor in the industry. However, other countries are constantly faced with a similar situation in one area or another. Moreover, there are examples of successful solutions to similar issues. One way to remedy the situation is to develop technology to determine the effectiveness of international cooperation in the mining industry.

Purpose. Thus, the purpose of the work is to find out the priority areas of international cooperation that can radically change the situation for the better in the mining industry of Ukraine, the criteria for their evaluation, as well as technologies (tools) to determine the effectiveness of international cooperation in this area.

Results. Ukraine ranks first in Europe in terms of quantity and quality of mineral deposits. Despite the fact that our country has an area of $0.4 \%$ of the world's land, our country's share in the world production is about $5 \%$ (more than $\$ 20$ billion for a year). Our country has a variety of mineral deposits. Before the outbreak of hostilities in Eastern Ukraine, its mining industry produced 93 types of minerals. According to the estimates of the Institute of Environmental Economics and Sustainable Development of the National Academy of Sciences of Ukraine, the gross value of minerals in the subsoil, prepared for exploitation, is about $\$ 7.5$ trillion. At the same time, the leading commodity countries of the world (Canada, USA, South Africa, and Australia) estimate our resource potential at $\$ 11.5$ trillion. For some types of minerals, production exceeds consumption. Thus, almost $30 \%$ of iron ore is exported from the country [1]. In the 1970s, Ukraine provided 
itself with its own resources and produced almost 70 billion cubic meters of natural gas [2].

Strong potential in Europe, significant achievements in the recent past, certain modern opportunities are reflected in the Energy strategy of Ukraine "Security, energy efficiency, competitiveness" for the period up to 2035. This document, in particular, notes that "Ukraine is and strives to remain one of the largest producers of hydrocarbons in continental Europe and a reliable transit of energy resources in the future (primarily natural gas and oil), providing a safe and reliable supply of energy resources to its own consumers and consumers of related markets, which must be extracted and delivered with a high level of environmental and social responsibility, with efforts to comply with commitments to reduce greenhouse gas emissions". The ways of achieving the declared goals are also quite clearly outlined. The document notes that a "significant mineral resource base and the priorities identified at the state level for its expansion to increase production of hydrocarbons to ensure energy independence of the country, as well as excess capacity in transportation, storage and processing of hydrocarbons, including their integration with the European market and opportunities to supply global markets for the future delivery in the EU, total amount to base the development of relevant industries and economy of Ukraine as a whole" [3]. It is also worth noting the presence of excess processing capabilities and logistics capacity, in addition to directly hydrocarbon deposits, long-term experience in their development and reliable markets.

However, the situation seems optimistic only at first glance. In addition, these are only declarative figures on paper. In reality, the Ukrainian mining industry features inefficiency, imbalance, and lack of innovation. Thus, the export of raw materials leads to the loss of significant revenues of the state (moreover, part of the exported mineral raw materials does not pass through other technological processes, and, accordingly, the final commodity products with the maximum added value are not created) [1]. The volume of natural gas consumption (mainly imported) is 1.7 times more than the volume of coal consumption (mainly domestic production) and almost twice above its share in the world fuel and energy balance (FEB). The FEB structure in Ukraine is economically impractical and threatens its energy and national security. According to experts, coal reserves in Ukraine will last for 350 years. At the same time, the transfer of all thermoelectric power plants from gas to coal will save about 6 billion cubic meters of gas per year. However, to fully meet the needs of thermal energy in solid fuel, it is essential to increase its production needs significantly, which is excluded by the fact that Ukrainian mines are in a neglected state [4].

The following characteristic feature of mining makes an additional obstacle: raw materials are alienated directly from nature, and therefore cannot be adapted for immediate direct use. A significant amount of excess mineral mass is produced in the production process. Storage of solid mineral waste can cause environmental pollution, and waste heaps can even change the wind regime and, accordingly, the climatic conditions of a particular area, reaching up to 200 meters in height. Solid waste also occupies some super-large areas, thus preventing the use of land for another, socially useful purpose. In addition, the mining industry is forced to make significant payments for land. Moreover, in the near future Ukraine will face further significant increase in depth of mining, complexity of the conditions of development of deposits, a decrease in the content of useful components and, consequently, increase in the content of harmful impurities, which will lead to higher development costs for less favorable fields, will require substantial long-term investment in infrastructure. Production waste can be used for many purposes, for example, for the production of building materials and fertilizers, but this requires additional funds and new technologies.

The cornerstone of economic growth in such a situation is the presence or absence of significant investments in the de- velopment of the mining industry. Investments in nanotechnology in the mining industry (underground gasification of coal, the creation of environmentally friendly liquid fuel from it, and others) are growing at a significant pace. For example, according to experts of the consulting company Cleantech Investor Network, they amounted to $\$ 1.2$ billion in 2013 . At the same time, investment in firms developing and implementing traditional technologies is falling [4]. However, Ukraine has extremely low innovation activity. According to such indicators as the level of research and development costs, the volume of business introduction of new technologies, public procurement of high-tech goods and attracting foreign investment, we are significantly lagging behind the neighboring countries, actually slowing down its innovative development [5].

It is difficult not to notice that the main problem on the way of investments in the mining industry of Ukraine is its monopolization, besides, the situation in this area over the past years is only getting worse. So, if in 2016 coal production by DTEK was $76.5 \%$ of the national production, now (data of 2018 ) it is $81.7 \%$. And this is with a constant fall in total production, which can be seen in Fig. 1 [6, 7].

In oil and gas production, the situation is actually similar, but with the dominance of Naftogaz (Figs. 2, 3) [6].

Thus, the share of Naftogaz in oil and oil condensate production was $88.1 \%$, in gas production $-78.9 \%$ at the end of last year, while during the year there was a tendency to increase it. It should also be pointed out that Naftogaz is a state-owned company, and this fact may be additional evidence of inefficiency and low innovation activity in the industry.

Monopolized markets are almost unable to attract investment in their own development. DTEK itself actively emphasizes the need for investment. The key value of reform is to increase competition. Maxym Tymchenko, General Director of DTEK, notes that when companies start competing for the consumer, the quality of service will improve, new services will appear, and production efficiency will improve [7]. It is difficult to disagree with this. Competition is not a balance, but a constant change, improvement and renewal of the industry, which is a continuous process, not a one-time temporary event, followed by a long lull. At the same time, today's advantages will be surpassed or nullified tomorrow. Competition forces us to reduce production costs, requires constant improvement of the technical base of production, finding ways to save raw products, materials, fuel and energy resources, working time, stimulates the improvement of the quality of products and services, encourages the introduction of new and modification of old products.

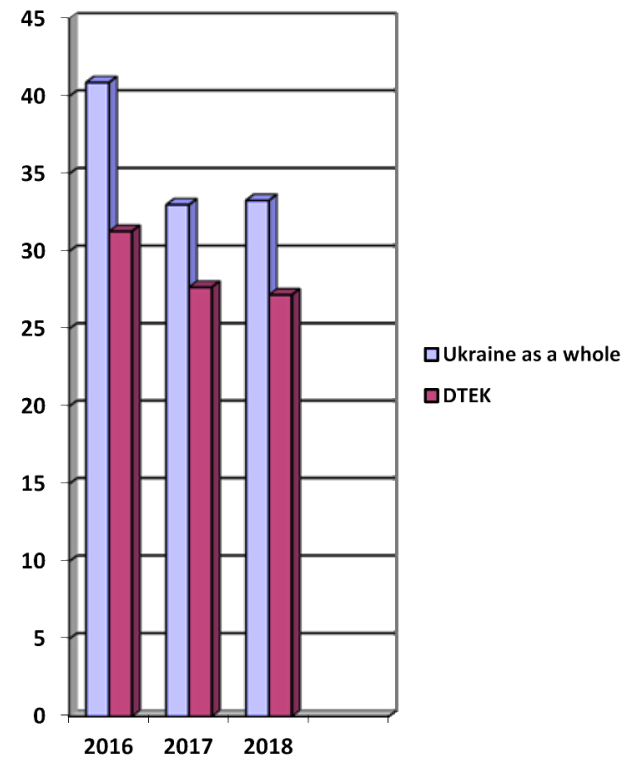

Fig. 1. Coal production, million tons 


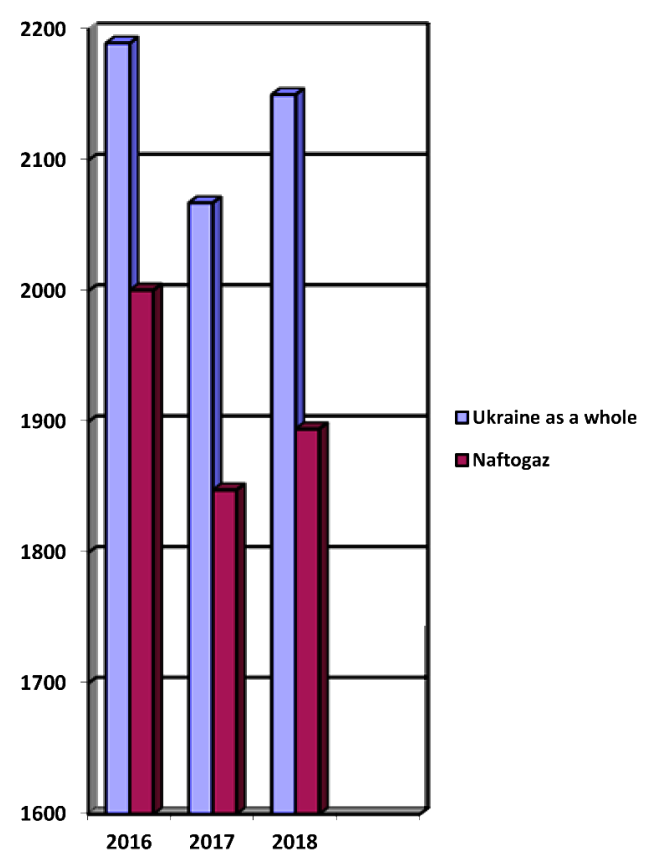

Fig. 2. Oil and gas condensate production in Ukraine, thousand tons

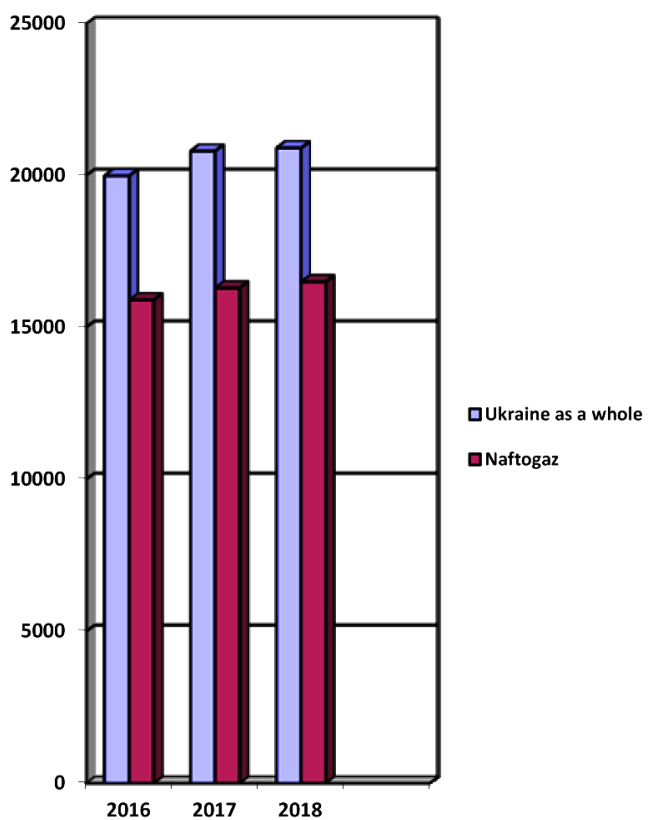

Fig. 3. Gas production in Ukraine, million square meters

In addition, competition covers all the relations of production and consumption, is the only possible means of achieving a balance between supply and demand and as a result - social needs and production [8]. The modern market prefers nonprice competition, which focuses not on the price of goods or services, but on their quality, reliability, service life, brand, advertising and the like. Such competition involves the allocation of products from a range of goods (services) for certain unique consumer properties and may include: maintenance of the product, the use of advanced forms of marketing, improvement of the company structure and functional parties of its activities, the specifics of demand, improving the quality of goods, advertising and wide range of additional services, improved after-sales service [9]. Such methods of competition are determined by the modern economic realities of developed countries. Their implementation radically transforms the interaction of market actors. You can see how the strategy of promotion of goods and services, consumer needs and opportunities to meet them go to a qualitatively new level. Along with other trends, all this changes the traditional view of the economy as a whole. However, the monopolization of the market leaves Ukraine aside from the advanced trends. Thus, international cooperation in the mining industry has a major role to contribute to the demonopolization of the industry. Therefore, it is necessary to determine its effectiveness with a priority focus on this indicator.

In the strategic forecasts of the development of the European Union until 2025, made by experts and analysts of the European Commission in 2017, it is noted that "currently Europe is witnessing a total digitalization of society, which blurs the boundaries between employees and the self-employed, between goods and services, as well as between buyers and sellers". The challenges of accelerating the use of technology, which are becoming more complex every day, affect the economy and society of all countries of the world, have an impact on the structure of employment, professions and industrial sectors. In this context, a serious problem arises for all countries of the world, which is how to respond to the technological challenges of our time, to create a scientific basis for the formation of an effective national development policy in order to maintain the proper level of national economic security with dynamic integration into the international economic space. If such a mechanism for managing the digital and technological economy is not found, countries will be threatened with the destruction of the economy and society, because, first of all, the national labor market will not meet the needs of the world's industry, and the economy becomes dependent on the import of human resources, technology and technology, which turns it from an economy as a balance of internal forces of supply and demand to a market. In turn, this can be interpreted as a direct threat to national economic security [10]. The point is that the further complication of dominant technologies and the resulting increase in the relative importance of quality work create the preconditions for the replacement of global, worldwide integration by regional integration of a very limited number of developed countries, which is carried out with minimal participation of the rest of the world. Thus, a new confrontation is formed on a global scale. To replace the old system of "East" - "West", in which the competition of cultures and values (or even their mutual enrichment) were predominant, a new and rather rigid scheme of "North" - "South" comes. This system includes, on the one hand, rich countries represented with serious material, intellectual, managerial and technological resources, and on the other - developing countries, states that are backward in economic terms, but in many cases with significant human and natural resources (this group includes Ukraine). This new model of international relations involves the flow of material, financial (in turn, converted from natural) and human resources (both in the form of cheap labor, which works for the rich "North", without leaving their own state, and due to the migration of qualified personnel) from the countries of the "South" to the countries that symbolize the "North". As a result of this process, rich countries continue to get richer, poor countries become even poorer. In fact, the organizational structures of international political relations are being transferred to the world economy. At the same time, the States of the "North" have a whole variety of mechanisms and means of preserving the existing state of things. Nor is there a clear positive relationship between "Northern" economic expansion to the South and the promotion of competition in developing countries. On the contrary, the invasion of stronger foreign competitors often leads to their monopolization of markets and production due to the rapid purchase of local potentially competing firms. Any compromise in such a scheme (this applies to both economic relations and the political sphere) can be achieved, first of all, by ignoring the interests of the so-called "South" countries, which are assigned the role of a supplier of resources in exchange for the 
possibility of metered use of modern technologies that are produced by the countries of the conditional "North".

A clear understanding of the realities of modern international relations should stimulate increased attention to the implementation of the latest "breakthrough" technologies. We see the obvious, at first glance, things. In addition, they are "on the surface" for decades. However, the situation as a whole does not change. Moreover, it becomes more complicated. Technologies in the mining industry of Ukraine remain extremely backward, and the world is moving forward with greater speed. Radical changes are possible only with the help of international cooperation on the adoption of technologies not only of a production nature, but also in the administrative sphere, with a kind of "planting" of a new mentality of the persons involved in this area.

If we continue to talk about the possibilities of improving the current situation, there are several interesting points. Of course, experts note the extreme importance of urgent modernization of all coal enterprises, namely: it is necessary to automate electric drives (pumps, fans, conveyors), modernize the lighting system and ventilation system, dispose of coal mine methane in cogeneration plants with electricity and heat production, apply a trigeneration system to produce cold for mine ventilation systems. That is, it is necessary to carry out accounting of energy resources, implement energy management, conduct energy audits, and introduce energy services. However, many focus on the other, which is of no less importance, and in our situation, even more. This concerns the problems to be solved in the administrative and legal sphere. Thus, the first priority is the introduction of electronic exchange trade in coal. Reforming the industry in this direction has significant advantages: the formation of an organized and open commodity market, transparency of activities and effective pricing, the creation of a transparent mechanism for the formation of price indices and quotations, the possibility of introducing derivative financial instruments, increasing the attractiveness of the industry during privatization, the impossibility of the emergence of illegal mining [2].

In addition, the issues of economic and legal regulation of mining relations in the event of cancellation of a special permit for the extraction of a certain type of mineral raw materials and the size and form of payments for the use of subsoil are unresolved. The mining relations are understood as the relations arising concerning the use of subsoil between the state as the owner of a natural resource and subsoil users. For example, in case of cancellation of a special permit for minerals issued by the Ministry of energy and environmental protection of Ukraine, the state will not reimburse the subsoil user investments that they provided in the development of the deposit or subsoil plot. Such legal non-regulation of this issue significantly increases the business risk of the subsoil user. This is a barrier to the growth of the number of mining enterprises in Ukraine. Every year, the state cancels dozens of special permits for mining, which hinders the development of the domestic mineral resource base. According to the State service of geology and subsoil of Ukraine, a total of 10,534 special permits were granted for the entire period of licensing (data as of January 1, 2015), including 4,569 - for geological exploration and geological study with pilot development, 5,882 - for mining, 81 - for other types of subsoil use. At the same time, the database of licensed objects takes into account 3,618 existing special permits, including 728 - for geological study and geological study with pilot development, 2,834 - for mining, 56 - for other types of subsoil use (data of SRDE "Geoinform Ukraine"). Thus, only $34 \%$ permits of the total number of issued special permits are valid.

It can be stated that the current system of subsoil use in the country does not meet the modern requirements of the transition of the economy to market relations. Today, uniform requirements and rules for subsoil use have not been formed yet, as well as uniform amounts of payments for the use of them have not been determined. Although the mineral resource base of Ukraine has a sufficient reserve of proven reserves of most types of minerals, it is at the stage of depletion of the subsoil now, which requires reforming the economic mechanism of their use [1].

The existing national market ensures the interests of only domestic players. Cross-border trade is limited. Therefore, trade is carried out exclusively through the mechanism of closed bilateral agreements. There are no properly functioning markets for capacity balancing and distribution services, as well as a retail market. For effective development of the wholesale market it is necessary to achieve real compliance with the principles of transparency and liquidity. The unpredictability and presence of significant legal, commercial, financial and political risks do not contribute to the growth of the investment attractiveness of the national market for foreign companies. This situation reduces the efficiency of the market, because such a market does not produce reliable price signals for consumers and producers. Due to the existence of special duties, independent suppliers do not have access to the production carried out by state-owned companies. State-owned mining companies cannot sell their resources on a market basis and receive the necessary profit for further investment in production growth. Consumers have no incentive to consume energy efficiently because they receive a regulated price through the existing subsidy system. Therefore, the creation of a successfully functioning market requires the following steps: ensuring liquidity; removing existing administrative barriers to trade; eliminating risks for trading; founding a universally recognized trading platform [5].

Thus, we see the following objectives of international cooperation in the mining industry: deregulation of the industry, removal of administrative obstacles and promotion of market transparency. In the overall technology for assessing the effectiveness of cooperation, they can be identified as the second most important component.

What else needs to be reformed and changed revolutionarily? How can international cooperation be useful? Certain problems of Ukrainian mines can be solved by the introduction of the concept of synchro-mining, in which the mine is not liquidated, but ceases its main activity in the presence of other profitable economic activities. The organizational mechanism of this concept is to integrate the industrial and scientific park to regulate the relationship between government and business, business and science during the development and implementation of innovative technologies. In foreign countries, there are examples of reorientation of unprofitable mines in other areas of activity: the creation of complexes for the purification and sale of drinking water (Germany), the functioning of museum complexes and their inclusion in the list of industrial tourism (Europe, Russia, the Baltic States) [11]. The experience and examples of mine closures in Europe prove that planned closures can improve infrastructure and open up new industries even before employment in the coal industry is cut, enabling miners to acquire new skills needed for further work before being laid off. But not only the management of the industry or the head of a separate mine should deal with this problem, but also local governments, trade unions and urban societies in order to take into account local characteristics to diversify the economy [12]. Non-core mining assets should not become a burden for local governments. They require a thorough audit of the possibility of creating small businesses on their basis for the development of the city's infrastructure or the provision of household and cultural services. By the way, along with solving the issue of closing unprofitable mines, their reorientation to other activities, as well as actually a radical restructuring of the way of life of the settlement, the usual existence of which was closely connected with the work of the mine complex, it is necessary to solve not only technical, material problems, but also normative ones, especially in the case of Ukraine. Given the fact that after the 
liquidation of the mining enterprise will remain large volumes of coal waste, the regulatory framework of waste management in Ukraine requires improvement. However, the use of coal mining waste can become quite a promising independent activity. Thus, mine water, ventilation air, waste heaps, associated rocks are inexhaustible sources of low-potential heat, which can be used in mining enterprises for the introduction of heat pump installations of hot water or to replace natural gas and coal for heating in boilers [12].

However, the cessation of production and reorientation of the enterprise is a serious step forward, the transition to another, higher level, but it is not yet the development of mining production directly. In this case, it is necessary to talk about expanding the capabilities of mining enterprises, increasing their investment attractiveness, notably through the introduction of new technologies. In this area, the priorities that are aimed at stimulating production and trade in the industry should be the following: 1) in the production of raw materials and primary products: a) harmonization of domestic standards in the field of standardization and certification of raw materials, which will provide for the improvement of administrative and legal regulation in the field of standardization, product quality, Metrology and certification, which is carried out in the state and is aimed at reducing the production of lowquality, and in some cases dangerous products that are manufactured in violation of the rules, norms and standards adopted in Ukraine and the world; b) update of the technical regulation system; c) elimination of duplication in the sphere of state supervision of conformity of products; d) simplification of procedures for production of Ukrainian materials; e) increased participation of technical regulatory institutions in European and international forums and events to ensure coordination and an effective information exchange system; 2) in the production segment: a) adaptation of industrial producers to environmental requirements for integration into global value chains: application of water and energy conservation technologies, reduction of resource use, reduction of greenhouse gas emissions and environmental pollution, use of environmentally friendly materials and raw materials; b) compliance with the requirements of environmental labeling, stimulation of domestic enterprises to reduce the energy intensity of production and the development of new production technologies, in particular, for the development of alternative energy, biodiversity conservation, and others; 3 ) in the marketing segment: a) branding of national production, strengthening the image and reputation of Ukrainian production of certain products through marketing activities, diplomatic activities for the strategic promotion of the country in the global economic system, b) formation and use of competitive advantages in the global market in order to create an image and reputation management to best realize the interests of the state [5]. Thus, the last component of the technology for determining the effectiveness of international cooperation in the mining industry should be recognized as its modernization. In general, the relevant technology can be represented in the form of such a scheme (Fig. 4).

Conclusions. It has been found that according to the gross value of minerals in the subsoil, prepared for exploitation, Ukraine ranks first in Europe. For some types of minerals, production exceeds consumption. At the same time, back in the 70s of the last century, Ukraine provided itself with its own resources and produced, among other things, almost 70 billion cubic meters of natural gas. However, today the characteristic features of the Ukrainian mining industry are inefficiency, imbalance, and lack of innovation.

It has been proved that the impetus for economic growth in this situation will be the presence of significant investments in the development of the mining industry, primarily in nanotechnology. The necessity of international cooperation in order to improve the situation in the industry has been substantiated.

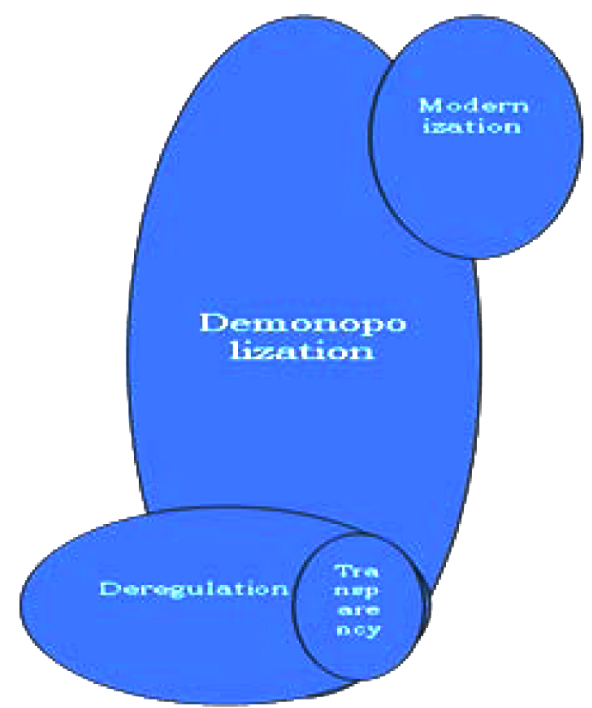

Fig. 4. Scheme of technology for determining the effectiveness of international cooperation in the mining industry

A scheme of technology for determining the effectiveness of international cooperation in the mining industry has been developed.

The European integration vector of international cooperation is constitutionally fixed, including in the mining industry. However, the scientific justification and details of individual moments can be the subject of further scientific research.

The article was prepared in the framework of the initiative research work "Technological dimension of international relations" (state registration number: 0119U100400; performed by the Department of International Relations of Oles Honchar Dnipro National University, supervisor - Ishchenko I. V., Dr. Sc. (Polit.), Cand. Sc. (Hist.), Assoc. Prof.).

\section{References.}

1. Shacz'ka, Z. Ya., \& Ganzyuk, T. D. (2016). Ways to improve the efficiency of mining enterprises in modern conditions. Prychornomorski ekonomichni studii, (10), 158-161.

2. Kovalenko, M.O. (2017). State and prospects of development of mining industry of Ukraine. Naukovyi Visnyk Khersonskoho Derzhavnoho Universytetu. Series: Economic Sciences, (22, Part 2), 170-172.

3. The Ministry of energy and environmental protection of Ukraine (n.d.). Energy strategy of Ukraine for the period up to 2035 "Safety, energy efficiency, competitiveness". Retrieved from http://mpe.kmu.gov.ua/minugol/control/uk/publish/ar ticle;jsessionid=430330FF801E34C1F3A0ED74AC670F8E. app1?art_id $=245239564 \&$ cat id $=245239555$.

4. Bondar-Pidhurska, O.V. (2014). Scientific and methodological aspects of innovative development of the mining industry in the context of sustainable growth. Naukovyi Visnyk Natsionalnoho Hirnychoho Universytetu, (1), 143-152.

5. Deyneko, L. V. (Ed.) (2018). The development of the industry to ensure the growth and renewal of the Ukrainian economy: analytical report. Kyiv: National Academy of Sciences of Ukraine, SI "Institute of Economics and Forecasting. National Academy of Sciences of Ukraine".

6. The Ministry of energy and environmental protection of Ukraine (n.d.). Retrieved from http://mpe.kmu.gov.ua/ minugol/control/uk/publish/.

7. DTEK Group (n.d.). Retrieved from https://dtek.com/ua/ media-center/press/.

8. Golda, N., \& Piniak, I. (n.d.). Competition as an objective market necessity. Retrieved from http://elartu.tntu.edu.ua/bitstream/ lib/26096/2/FMZKP 2018v1 Golda N-Competition as objective_123-125.pdf. 
9. Sobolieva, M.V. (2016). Non-price methods of market competition in the conditions of globalization. Visnyk $\mathrm{ONU}$ imeni I.I. Mechnykova, 21(8(50)), 17-21.

10. Khmara, M. P. (2018). High-tech clusters as a mechanism for ensuring the economic security of the world's countries. Efektyvna Ekonomika, (2), 1-7.

11. Russiyan, O.A., \& Karnaukh, V.V. (2017). Safety in the workplace of a coal mining enterprise as an integral part of the concept of decent work: foreign experience and Ukrainian realities. Naukovyi Visnyk Mizhnarodnoho Humanitarnoho Universytetu, (26), 110-114.

12. Boichenko, M. V. (2018). Ways out of the crisis of mining enterprises to achieve their sustainable development. Ekonomichnyi Visnyk Donbasu, 3(53), 21-24.

\section{Технологія визначення ефективності міжнародного співробітництва України в гірничодобувній галузі}

\section{І. В. Іщенко, О. Ю. Висоцький, В. О. Пермінов}

Дніпровський національний університет імені Олеся Гончара, м. Дніпро, Україна, e-mail: iv.ishchenko@gmail. com; vysalek@gmail.com; finstruk@ukr.net

Мета. Визначення пріоритетних напрямів міжнародного співробітництва, здатних докорінно змінити у кращий бік ситуацію в гірничодобувній галузі України, критеріїв їх оцінки й технологій (інструментів) ефективного міжнародного співробітництва у цій сфері.

Методика. Для досягнення мети дослідження використано структурно-компонентний аналіз проблемних питань розвитку гірничодобувної промисловості України. Також застосовувалися загальнонаукові методи порівняння, аналогії, дескриптивний аналіз.

Результати. У процесі дослідження з'ясовано, що за валовою цінністю копалин у надрах, підготовлених до експлуатації, Україна посідає перше місце в Європі. За деякими видами корисних копалин видобуток перевищує споживання. При цьому, ще у $70-x$ роках минулого століття Україна забезпечувала себе власними ресурсами й видобувала серед іншого майже 70 млрд. м $^{3}$ природного газу. Проте сьогодні характерними рисами української гірничодобувної галузі є неефективність, незбалансованість, відсутність інновацій. Доведено, що поштовхом до економічного зростання в такому положенні стане наявність значних інвестицій у розвиток гірничодобувної промисловості, у першу чергу, у нанотехнології. Обгрунтована необхідність міжнародного співробітництва з метою покрашення ситуації в галузі. Розроблена схема технології визначення ефективності міжнародного співробітництва в гірничодобувній галузі.

Наукова новизна. Проведене комплексне дослідження гірничодобувної галузі України в контексті можливостей, що надає міжнародне співробітництво у цій сфеpi, запропонована модель оцінки ефективності цього співробітництва.

Практична значимість. Обгрунтовані в дослідженні тези та запропоновані моделі визначення ефективності міжнародного співробітництва $є$ придатними для використання при плануванні регіонального розвитку та для підготовки відповідних державних програм.
Ключові слова: гірничодобувна галузь, економічне зростання, інвестиціі, демонополізація, synchro-mining, інноваціі

\section{Технология определения эффективности международного сотрудничества Украины в горнодобывающей отрасли}

\section{И. В. Ищенко, А. Ю. Высоцкий, В. А. Перминов}

Днепровский национальный университет имени Олеся Гончара, г. Днепр, Украина, e-mail: iv.ishchenko@gmail. com; vysalek@gmail.com; finstruk@ukr.net

Цель. Определение приоритетных направлений международного сотрудничества, способных в корне изменить в лучшую сторону ситуацию в горнодобывающей отрасли Украины, критериев их оценки и технологий (инструментов) эффективного международного сотрудничества в этой сфере.

Методика. Для достижения цели исследования использован структурно-компонентный анализ проблемных вопросов развития горнодобывающей промышленности Украины. Также применялись общенаучные методы сравнения, аналогии, дескриптивный анализ.

Результаты. В процессе исследования установлено, что по валовой ценности ископаемых в недрах, подготовленных к эксплуатации, Украина занимает первое место в Европе. По некоторым видам полезных ископаемых добыча превышает потребление. При этом, еще в 70-х годах прошлого века Украина обеспечивала себя собственными ресурсами и добывала среди прочего почти 70 млрд. м $^{3}$ природного газа. Однако сегодня характерными чертами украинской горнодобывающей отрасли является неэффективность, несбалансированность, отсутствие инноваций. Доказано, что толчком к экономическому росту в таком положении станет наличие значительных инвестиций в развитие горнодобывающей промышленности, в первую очередь, в нанотехнологии. Обоснована необходимость международного сотрудничества с целью улучшения ситуации в отрасли. Разработана схема технологии определения эффективности международного сотрудничества в горнодобывающей отрасли.

Научная новизна. Проведено комплексное исследование горнодобывающей отрасли Украины в контексте возможностей, которые предоставляет международное сотрудничество в этой сфере, предложена модель оценки эффективности этого сотрудничества.

Практическая значимость. Обоснованные в исследовании положения и предложенные модели определения эффективности международного сотрудничества пригодны для использования при планировании регионального развития и для подготовки соответствующих государственных программ.

Ключевые слова: горнодобывающая отрасль, экономический рост, инвестиции, демонополизация, synchro-mining, инновации

Recommended for publication by H. P. Shchedrova, Doctor of Political Sciences. The manuscript was submitted 29.03.19. 